Article

\title{
Birds of a Feather Flock Together: The Inclusive Effect of Similarity Patterns in Equity Crowdfunding
}

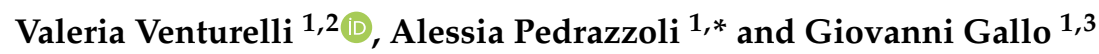 \\ 1 Marco Biagi Department of Economics, University of Modena and Reggio Emilia, 41121 Modena, Italy; \\ valeria.venturelli@unimore.it \\ 2 CEFIN (Centre for Research in Banking and Finance), University of Modena and Reggio Emilia, \\ 41121 Modena, Italy \\ 3 National Institute for the Analysis of Public Policies (INAPP), 00198 Rome, Italy; gi.gallo.ext@inapp.org \\ * Correspondence: alessia.pedrazzoli@unimore.it; Tel.: +39-059-2056811
}

Received: 26 March 2020; Accepted: 24 April 2020; Published: 26 April 2020

check for updates

\begin{abstract}
Crowdfunding is helping to drive financial inclusion by expanding the availability of funds to traditionally excluded and underserved groups of individuals, such as ethnic minority and female entrepreneurs. This study verifies how ethnic and gender similarity between investor and entrepreneur can affect the invested amount in an equity crowdfunding campaign. Using an integrated approach with linear regression and Shapley decomposition, we analyze 8600 investments made by 5996 unique personal shareholder investors in 81 equity crowdfunding campaigns. Results show that similarity patterns seem to significantly influence the amount invested in a campaign but their effects change according to investor's gender and ethnic origin. In fact, even if female investors give a higher amount to men-led companies, their preference changes if the company is run by a female founder belonging to the same ethnic minority group. Results emphasize equity crowdfunding's potential as a tool for the financial inclusion of ethnic minority groups of investors and entrepreneurs.
\end{abstract}

Keywords: equity crowdfunding; ethnic similarity; financial inclusion; investment factors

\section{Introduction}

Crowdfunding industry is revolutionizing the financial services market, by allowing to obtain financial resources required for developing new products and technological innovations competing with traditional entrepreneurial finance players [1]. Among crowdfunding models, equity crowdfunding is expected to democratize access to finance by increasing capital availability for micro, small and medium enterprises (MSMEs), by reducing social structure constraints and by enabling entrepreneurs to better promote their investment requests to a new wave of investors [2-5].

In this framework, this study verifies whether and how the ethnic and gender similarity among founder and investor affects the invested amount in an equity crowdfunding campaign, allowing for a better understanding of the role played by equity crowdfunding as a transformative tool for supporting the financial inclusion of female and ethnic minority entrepreneurs and investors, thus filling a gap still existing in the empirical literature [6].

Currently, studies on crowdfunding primarily focus on the demand side, highlighting which characteristics of entrepreneurs and their start-ups are determinants of campaign success [7-12]. From the supply side, most prior scholarly research has concentrated on ascertaining investors' motivations for participating in crowdfunding campaigns [13-15] or on detecting biases that affect investment decisions [16]. Among the latter, several studies have pinpointed the presence of gender similarity 
effect for which female investors support female entrepreneurs, that especially in the financing market have difficulty gaining access to external capital for the creation of new ventures $[2,17,18]$.

The empirical evidence shows that financial resources to start new ventures are particularly problematic for female entrepreneurs, but also for other groups of entrepreneurs such as those from ethnic minorities, who often force them toward informal sources of capital or to resort to personal networks [19-22]. Equity crowdfunding may present a new tool for overcoming the financial constraints also for ethnic minority entrepreneurs, since similarity of ethnic profile between entrepreneur and investors may be crucial in generating trust and reducing information asymmetry between them [23-25]. The academic literature on ethnicity and crowdfunding is in its infancy [26-28] and usually it does not include ethnic-based similarity because of the difficulty of distinguishing members of ethnic groups [29].

Finally, we did not find any studies that combine ethnic and gender similarity in analyzing how their coexistence influences the invested amount on equity crowdfunding campaigns. The diverse backgrounds of participants in equity crowdfunding markets permits greater nuance in studying the influence of similarity attraction in funding decisions, so studies about the matching between entrepreneurs and investors are needed [6].

To verify whether and how ethnic and gender similarity increase the amount invested by a single crowdfunding investor, we collected information on 8600 investments made by 5996 unique personal shareholder investors on the British equity crowdfunding platform Crowdcube. For this study, only the projects that were successfully concluded have been selected; those that did not reach the end or those failed and cancelled by the platform are not part of the analysis. Information from founders and shareholders were obtained from documents filed and hosted on the Companies House website (companieshouse.gov.uk). To identify investors' gender, we use the genderize.io tool, while details of ethnic origin are obtained by surname geographic distribution using forebears.io, a genealogical source.

Our results show that, in equity crowdfunding, ethnic and gender similarities play different roles depending on the investor's characteristics-ethnicity, gender or a combination of the two. Particularly, while, in general, in equity crowdfunding, female investors give a higher amount to men-led companies, ethnic minority female investors invest a higher amount if the company is run by a female founder belonging to the same ethnic minority, thus indicating the existence of a similarity effect driven by ethnicity.

Among the aspects that influence the variability of the amount invested, those detected through a Shapley decomposition [30], founder profile and company characteristics are the most significant; nonetheless, ethnic and gender similarities, as sociodemographic aspects, also have a non-negligible influence on the heterogeneity of the total amount invested.

Our results, contribute, at first, to the literature on similarity effect in the context of entrepreneurial finance (e.g., $[23,25,29])$ considering both ethnic and gender similarity. Second, our work is among the few recent papers that analyze shareholders' characteristics and the determinants of the amount invested (e.g., [31,32]). In fact, with respect to the previous crowdfunding literature [29,33], where similarity is usually proxied by the number of female/male investors involved in the campaign, our study considers the actual amount invested in the campaign by the single investor. In equity crowdfunding context, compared to donation or reward-based crowdfunding, the actual level of amount invested is a more precise representation of the effective degree of investor participation and engagement in the company that can condition the investment evaluation process. Investors after an equity crowdfunding campaign became company's shareholders, sharing the risks associated with the uncertainty surrounding the implementation of business ideas, the profitability of start-up and the lack of a secondary market for pricing, liquidation and exit.

Finally, our study extends the framework of crowdfunding as a tool for strengthening financial inclusion by showing it to be a meaningful support for ethnic minority entrepreneurs, enabling them to better promote their investment requests to a new wave of investors. Researchers and policy makers alike are offered the opportunity to evaluate potential financial inclusion issues with relevant data. 
The remainder of the paper is organized as follows. Section 2 reviews the relevant literature and posits the research questions. Sections 3 and 4 present the data and variables used in the empirical analysis while Section 5 presents the main results and reports the robustness tests. Finally, Section 6 discusses and concludes the paper, pointing out its implications, limits and future research directions.

\section{Related Literature and Hypotheses Development}

The 'similarity effect' is the tendency of the members of a group to display a preference for associating with other members of the same group. This tendency is often described as 'birds of a feather flock together' or homophily [24,34]. Lazarsfeld and Merton [35] distinguish between two types of homophily: status homophily, in which similarity is based on informal, formal, or ascribed status, and value homophily, which is based on values, attitudes, and beliefs. Status homophily includes the main sociodemographic factors such as race, ethnicity, gender or age, and acquired characteristics such as religion, education, occupation or behavioral patterns. This pure, preference-based mechanism highlights the role of personal similarities in breeding connections and is a basic organizing principle present across a wide range of social interaction contexts such as friendship, social relations and business alliances [36]. Among status homophily factors, ethnicity creates the strongest divides in our personal environments and researchers have found strongly homophilous association patterns by race and ethnicity [36]. Race is an ascribed category linked to genetic, biological and physical features that characterize a group of people, and racial group membership changes across time and context [37]. Ethnicity, on the other hand, is a category that reflects a group's common history, nationality, geography, language and culture, and the status it refers to is less reductionist than that of race [37]. When ethnicity refers to a group, it implies that members have some awareness of group membership and a common national background and culture [38]. When ethnicity is linked to business founding, it represents a set of connections and social structures among the members of an ethnic group and the ways in which those social structures are used [39].

Interpersonal similarity has received significant research attention in sociology, but we do not know much about its impact on investment decisions.

Research on crowdfunding focuses principally on status homophily, considering investors' gender as common basis for similarity. In donation projects, female capital providers prefer to support projects founded by women rather than those founded by men because of the gender similarity between female backers and entrepreneurs [2,17,18]. Greenberg and Mollick [29] put forward an explanation for this phenomenon by introducing the concept of activist choice homophily: that is, the desire of female investors to support female entrepreneurs in technology industries due to the perceived unjustified barriers that women have to face in that sector. For equity crowdfunding campaigns, Vismara et al. [33] conclude that the number of female investors is considerably higher in female-led campaigns, that also display higher success rates, while the number of male investors is slightly higher in campaigns launched by male-led firms. Horvat and Papamarkou [40] find similar results.

To the best of our knowledge, the academic literature on ethnicity and equity crowdfunding does not include ethnic-based similarity, although the online context where crowdfunding is developed can improve solidarity within ethnic minority groups, mobilizing ethnic networks [27] and in-group favoritism [41]. In other entrepreneurial financial contexts, only few studies analyze how ethnic similarity influences the mobilization of funding resources. In the venture capital selection process, shared ethnicity between founder and venture capital team increases the probability of an investment match and has high predictive power for early-stage investments [23,24]. Moreover, it also influences the preference to collaborate with other venture capitalists [25].

The operation of similarity leads us to the following predictions:

H1a. The amount invested in an equity crowdfunding campaign is higher when there is an ethnic similarity between investor and founder. 
H1b. The amount invested in an equity crowdfunding campaign is higher when there is a gender similarity between investor and founder.

Another important finding is that the more similarity patterns there are between two individuals, on both sociodemographics characteristics and values, attitudes, and beliefs, the stronger the interpersonal connections they create [42,43]. "The patterns of homophily tend to get stronger as more types of relationships exist between two people, indicating that homophily on each type of relation cumulates to generate greater homophily for multiplex than simplex ties" [36] (p. 418). About gender and ethnic origin, people of the same gender and ethnic group should prefer to support each other because of the perceived trust in the members of their group [44]. In this sense, equity crowdfunding represents the ideal setting to test the effect of multiple similarity patterns on the level of amount invested. The following prediction can be stated:

H2. The amount invested in an equity crowdfunding campaign is higher when ethnic and gender similarity coexists between investor and founder.

\section{Data and Research Design}

\subsection{The Data Collection}

We collected data from Crowdcube, the largest generalist equity crowdfunding platform in the UK [45], funded in 2011, and from Companies House website. At first, we collected information on campaigns posted on Crowdcube from October 2011 to January 2016. We only considered the first equity crowdfunding campaign successfully run by a single company and where the proponent was a physical person. In total, we collected information on 244 equity crowdfunding campaigns. Then, we checked for the presence of information for each of the Crowdcube's campaigns on Companies House website. We found the complete set of documents and the full list of shareholders only for 81 out of the 244 companies. In particular, on Companies House website, we were able to extract the name and the surname of the founder and the full list of shareholders from the Annual Return form (Module AR101), filed in accordance with Section 854 of the Companies Act 2006, at the dates immediately after and immediately before the campaign. On AR101 module, we collected also the number of shares subscribed by each investor. The price of shares, when not disclosed directly in the AR101 module, was obtained by dividing the amount collected during the equity crowdfunding campaign by the total number of shares subscribed by investors during the campaign.

For this study, only the projects that were successfully concluded, closed, and all personal investments collected have been selected; those that did not reach the end or those failed and cancelled by the platform are not part of the analysis. For failed campaigns, the platform does not publish the level of amount invested by each participant during the fundraising. Therefore, once the campaign has fully funded and is closed for investment, investors have a cooling off period of seven days where they can choose to reduce or withdraw the investment amount (Crowdcube.io). The list of shareholders publicly available on Module AR101 is composed of all confirmed amounts invested and future new company's shareholders.

The dataset includes 8683 investments made by 6030 investors. For the purpose of our analysis, we exclude the 83 investments (nearly $1 \%$ in terms of number of investments and less than $6 \%$ in terms of amount invested) made by 34 legal entities.

\subsection{Identification of Ethnicity and Gender}

In the empirical analysis, various methodologies have been used to identify individual ethnicity, such as direct survey [46,47], post-secondary education in the biographies [48], and inference from individual names [23,24,49-51]. For identifying founders' and investors' ethnicity, we refer to the last methodology, looking for the individual's surname on the forebears.io tool, a genealogical source, which includes information on the geographical distribution of 27 million surnames. The algorithm returns 
the nation in which the surname occurs, the frequency of a specific surname, and the rank by incidence. We create the final matching list in several steps. First, to identify ethnicity, we consider the nation with the highest incidence and the densest occurrence. Second, for surnames with different incidence and density as in Bengtsson and Hsu [23], we hand-checked ethnic background with the surname-matching algorithm developed by Kerr [51,52] and with information stemming from different sources such as ancestry.com as in Bhagwat and Liu [49], which provides a distribution of U.S. immigrants based on port entry records. Only for female investors, we cross-check on Onolytics software the ethnic group attribution using the investors' full name [53]. This check has been done to control for the female practice, especially in Anglo-Saxon countries, of adopting the husband's surname.

Individual investors' ethnicity is divided into nine groups (more details on classification are available upon request to the authors): African, Anglo-Saxon, Arabic, Asian, Oriental Bloc, European, Israeli, Southern African, and Latin American. This classification is in line with the one usually adopted in studies focused on the evaluation of the financial constraints faced by certain ethnic minority communities [54-56]. Most investors have Anglo-Saxon origin (69.8\%), followed by those with Asian (9.4\%) and European (8.1\%) origins. African, Oriental, Latin American, Arabic, Southern African, and Israeli investors represent the remaining $13 \%$ of our sample. To understand the potential of capital availability for these traditionally underrepresented groups, we focus on two main investor groups: the dominant group, that is, investors that belong mainly to British and European origin ethnic groups (Anglo-Saxon, European, Oriental Block, Southern African, and Israeli), and the minority group, that is, investors that belong to underrepresented ethnic groups in the British and European financial market (Asian, African, Latin American, and Arabic).

Founders' gender is directly available on the information stored on Company House website while investors' gender is inferred through automated methods since this information is not published in the filed documents. Following previous studies $[6,29,57]$, we use the genderize.io tool to compare first names with a database including 86,710 distinct names across 81 languages. The algorithm returns the gender and the probability that the name-gender attribution was correct; a probability higher than $90 \%$ was found for the vast majority of the assignments, thus suggesting the high degree of accuracy of the method. When probability is less than $90 \%$ or the algorithm returns no attribution or in cases of unisex names, we cross-check the accuracy of the codes and complete the missing variables using LinkedIn and Facebook user profile pictures and Google Search.

\subsection{The Sample Descriptive Statistics}

Our final sample includes 8600 investments made by 5996 unique personal shareholder investors in 81 equity crowdfunding campaigns. Female investors represent nearly $23 \%$ ( $18 \%$ in terms of number of investments) of the total, while ethnic minority investors constitute nearly $18 \%$. More than $40 \%$ of the total number of investments are carried out by the so called "serial" investors, that is to say, investors with at least two investments made (Table 1-Panel A). Our sample is a broad cross-section of companies from different industries and of various ages at the time of the equity crowdfunding campaigns (Table 1-Panel B). On average, the firms in the sample are 2.2 years old with a maximum of 11 years, more than $20 \%$ belonging to highly innovative sectors on the basis of SIC codes and with an average team size of 3.6 people. In terms of campaign structure (Table 1-Panel C), we observe the goal amount-i.e., the target amount of money set in each campaign - the percentage of total equity offered-i.e., the percentage of equity that a management team plans to offer to investors prior to the offering - the number of exit strategies-i.e., the pre-planned strategies of how an investor can get out of an investment as proposed by the founder during the campaign such as IPOs, trade sale, share buy-back, etc., and the total amount raised at the end of the campaign-i.e., the effective total amount of capital raised during the campaign that can be different from the goal amount in case of an overfunded campaign. On average, the logarithm of the goal amount is $11.6(£ 185,033)$ while the logarithm of the amount raised is $11.8(£ 223,153)$ with a maximum of $14.5(£ 1.9 \mathrm{~m})$ and a minimum of 
$9.4(£ 10,000)$. The percentage of equity offered in our sample is nearly $18 \%$, and 65 campaigns (more than $80 \%$ ) envisage at least one exit strategy.

Table 1. Summary statistics of the key variables.

\begin{tabular}{|c|c|c|c|c|c|c|}
\hline Panel A: Sample Overview & Obs & & & & & \\
\hline Number of equity crowdfunding campaigns & 81 & & & & & \\
\hline Number of investments made by personal investors & 8600 & & & & & \\
\hline Number of investments made by ethnic minority investors & 1568 & & & & & \\
\hline Number of investments made by dominant investors & 7032 & & & & & \\
\hline Number of unique ethnic minority investors & 1064 & & & & & \\
\hline Number of unique dominant investors & 4932 & & & & & \\
\hline Number of investments made by female investors & 1603 & & & & & \\
\hline Number of investments made by male investors & 6997 & & & & & \\
\hline Number of unique female investors & 1361 & & & & & \\
\hline Number of unique male investors & 4635 & & & & & \\
\hline Number of investments made by serial investors & 2526 & & & & & \\
\hline Panel B: Companies & Obs & mean & $\min$ & p50 & $\max$ & $\mathrm{Sd}$ \\
\hline Company age at the date of the ECF campaign (in years) & 81 & 2.2 & 0 & 2 & 11 & 2.3 \\
\hline Company sector Innovative $(1=$ yes; $0=$ no) & 81 & 0.2 & & & & 0.4 \\
\hline Team size (number) & 81 & 3.6 & 1 & 3 & 12 & 2.8 \\
\hline Panel C: Campaigns & Obs & mean & $\min$ & p50 & $\max$ & $\mathrm{Sd}$ \\
\hline Goal amount $[\operatorname{Ln}(£)]$ & 81 & 11.6 & 9.2 & 11.5 & 14.5 & 1.0 \\
\hline Total equity offer (in \%) & 81 & $17.7 \%$ & $4.0 \%$ & $16.8 \%$ & $48.0 \%$ & 0.1 \\
\hline Exit strategies (number) & 81 & 0.8 & 0 & 1 & 1 & 0.4 \\
\hline Total amount raised $[\mathrm{Ln}(£)]$ & 81 & 11.8 & 9.4 & 11.8 & 14.5 & 1.0 \\
\hline Panel D: Investors & Obs & mean & $\min$ & p50 & $\max$ & $\mathrm{Sd}$ \\
\hline Investors per campaign (number) & 81 & 106 & 8 & 83 & 394 & 81 \\
\hline Ethnic minority investors per campaign (number) & 81 & 19 & 1 & 15 & 75 & 16.7 \\
\hline Fraction of ethnic minority investors per campaign (\%) & 81 & $17.5 \%$ & $6.3 \%$ & $17.4 \%$ & $35.5 \%$ & 0.1 \\
\hline $\begin{array}{l}\text { Fraction of dollar amount ethnic minority investors invested } \\
\text { per campaign (\%) }\end{array}$ & 81 & $19.9 \%$ & $0.9 \%$ & $18.8 \%$ & $70.7 \%$ & 0.2 \\
\hline Female investors per campaign (number) & 81 & 20 & 1 & 12 & 125 & 24 \\
\hline Fraction of female investors per campaign (\%) & 81 & $17.5 \%$ & $3.6 \%$ & $15.4 \%$ & $45.6 \%$ & 0.1 \\
\hline $\begin{array}{l}\text { Fraction of dollar amount female investors invested per } \\
\text { campaign }(\%)\end{array}$ & 81 & $23.0 \%$ & $1.7 \%$ & $17.3 \%$ & $50.6 \%$ & 0.2 \\
\hline Amount invested by personal investors $[\operatorname{Ln}(£)]$ & 8600 & 5.65 & 0.2 & 5.53 & 14.15 & 2.0 \\
\hline Amount invested by ethnic minority investors $[\operatorname{Ln}(£)]$ & 1568 & 5.45 & 1.74 & 5.3 & 11.48 & 2.0 \\
\hline Amount invested by dominant investors [Ln $(£)]$ & 7032 & $5.69 *$ & 0.2 & 5.58 & 14.15 & 2.0 \\
\hline Amount invested by female investors [Ln $(£)]$ & 1603 & 5.41 & 1.21 & 5.3 & 11.85 & 2.0 \\
\hline Amount invested by male investors [Ln $(£)]$ & 6997 & $5.70 *$ & 0.2 & 5.58 & 14.15 & 2.0 \\
\hline Amount invested by non-serial investors [Ln $(£)]$ & 6074 & 5.88 & 2.08 & 5.9 & 14.15 & 2.1 \\
\hline Amount invested by serial investors $[\operatorname{Ln}(£)]$ & 2526 & $5.09 *$ & 1.75 & 4.99 & 10.85 & 1.8 \\
\hline Panel E: Founders & Obs & mean & $\min$ & p50 & $\max$ & $\mathrm{Sd}$ \\
\hline Founders (number) & 81 & 1.3 & 1 & 1 & 3 & 0.5 \\
\hline At least 1 ethnic minority founder & 81 & 0.2 & 0 & 0 & 1 & 0.4 \\
\hline At least 1 female founder & 81 & 0.2 & 0 & 0 & 1 & 0.4 \\
\hline
\end{tabular}

Notes: * Difference in mean values with respect to the complementary group (respectively, "dominant/ethnic minority", "female/male", "non-serial/serial") is statistically significant at $1 \%$ level.

The average number of investors per campaign is 106, with the most crowded campaign involving 394 investors. On average, the logarithm of amount invested by the single investor is 5.6 (£2102); preliminary findings from our sample highlight the fact that women $(£ 1766)$ and people belonging to an ethnic minority ( $£ 1724)$ tend to invest a lower amount of $£$ than men (£2179) and those belonging to the dominant ethnicity (£2186) respectively (Table 1-Panel D). Our descriptive evidence on the lower amount invested by female investors at the mean and the median is in line with the results of Hervé et al. [32], from Wiseed, a French Platform. The under-representativeness of women among investors in equity crowdfunding campaigns or among people making venture and angel capital investments is confirmed by other studies in the literature (e.g., [32,33,58,59]). 
Finally, the average number of founders is 1.3 with a maximum of 3 . Additionally, in this case, women and people belonging to an ethnic minority turn out to have a lower entrepreneurship level than the others, since only 20 percent of campaigns have at least one female or at least one ethnic minority proponent (Table 1-Panel E). These findings are likely to be related to the fact that in a financial and entrepreneurial context, females generally report a higher risk aversion and lower financial resources $[60,61]$ while ethnic minorities show lower level of business-related experiences [62].

\subsection{Ethnic and Gender Similarities}

The main objective of this paper is to provide empirical-based indicators on the effect of ethnic and gender similarities on amount invested in an equity crowdfunding campaign. Before that, this section presents some findings on the presence of these similarities in our sample of investors.

Co-ethnicity, thus, the case in which macro-ethnicity of investor and at least one founder is the same, accounts for nearly $70 \%$ of all cases (Table 2-Panel A). As for co-gender, thus, cases in which the gender of investor and the gender of at least one founder matches, Table 2-Panel B shows that it accounts for nearly $68 \%$ of investments. Specifically, of the 1946 investments made in female-led companies, $425(21.8 \%)$ are attributed to female investors, while of the 6654 investments made in male-led companies, $5476(82.3 \%)$ are attributed to male investors.

As an econometric deepening on this aspect, we developed some Probit estimations on the probability to invest in an equity crowdfunding campaign with at least one female proponent. Results confirm, with a statistically significance at $1 \%$ level, that women tend to invest more frequently in this type of campaign, even when controlling for other individual characteristics (i.e., ethnicity and seriality) and for campaign characteristics. The same occurs for investors belonging to an ethnic minority with regard to the probability to invest in a campaign with at least one ethnic minority proponent.

Table 2-Panel C points out how the two similarities cross to each other in our sample of investments. The coexistence of both gender and ethnic similarities represents the most common case in our sample ( $40.6 \%$ of the total), while only $14.6 \%$ of investments report neither gender nor ethnic similarity between investor and at least one founder.

Finally, Table 2-Panel D reports the average amount invested (in logarithmic terms) by ethnic and gender similarity. These descriptive evidences allow us to draw some preliminary considerations on the hypotheses defined in Section 2. First, tests on differences in mean values between investments characterized by gender (ethnic) similarity and those where there is no gender (ethnic) similarity show that the amount invested in an equity crowdfunding campaign is significantly higher in case of gender (ethnic) similarity. Therefore, they seem to overall confirm both H1a and H1b. Second, statistical significance tests also reveal that the amount invested, on average, in a campaign when both gender and ethnic similarities coexist (5.86 or $£ 2490$ ) is significantly higher than the one reported in the other three cases (i.e., "neither gender nor ethnic similarity", "ethnic similarity only" and "gender similarity only"). This additional evidence preliminary confirms $\mathrm{H} 2$ too, thus, the amount invested is further higher in the case of coexistence of gender and ethnic similarity between the investor and at least one founder. 
Table 2. Number of investments and amount invested by similarity.

\begin{tabular}{|c|c|c|c|}
\hline \multicolumn{4}{|c|}{ Panel A: Number of Investments by Ethnic Similarity } \\
\hline \multirow{2}{*}{ Investor ethnicity } & \multicolumn{2}{|c|}{ Founder ethnicity } & \multirow{2}{*}{ Total } \\
\hline & Dominant & Minority & \\
\hline \multirow{2}{*}{ Dominant } & 5684 & 1348 & 7032 \\
\hline & $66.1 \%$ & $15.7 \%$ & $81.8 \%$ \\
\hline \multirow{2}{*}{ Minority } & 1203 & 365 & 1568 \\
\hline & $14.0 \%$ & $4.2 \%$ & $18.2 \%$ \\
\hline \multirow{2}{*}{ Total } & 6887 & 1713 & 8600 \\
\hline & $80.1 \%$ & $19.9 \%$ & $100.0 \%$ \\
\hline \multicolumn{4}{|c|}{ Panel B: Number of investments by gender similarity } \\
\hline \multirow{2}{*}{ Female investor } & \multicolumn{2}{|c|}{ Female founder } & \multirow{2}{*}{ Total } \\
\hline & No & Yes & \\
\hline \multirow{2}{*}{ No } & 5476 & 1521 & 6997 \\
\hline & $63.7 \%$ & $17.7 \%$ & $81.4 \%$ \\
\hline \multirow{2}{*}{ Yes } & 1178 & 425 & 1603 \\
\hline & $18.6 \%$ & $4.9 \%$ & $18.6 \%$ \\
\hline \multirow{2}{*}{ Total } & 6654 & 1946 & 8600 \\
\hline & $77.4 \%$ & $22.6 \%$ & $100.0 \%$ \\
\hline \multicolumn{4}{|c|}{ Panel C: Number of investments by ethnic and gender similarity } \\
\hline \multirow{2}{*}{ Gender similarity } & \multicolumn{2}{|c|}{ Ethnic similarity } & \\
\hline & No & Yes & Total \\
\hline \multirow{2}{*}{ No } & 1254 & 2414 & 3668 \\
\hline & $14.6 \%$ & $28.1 \%$ & 42.7 \\
\hline \multirow{2}{*}{ Yes } & 1445 & 3487 & 4932 \\
\hline & $16.8 \%$ & $40.6 \%$ & $57.4 \%$ \\
\hline \multirow{2}{*}{ Total } & 2699 & 5901 & 8600 \\
\hline & $31.4 \%$ & $68.6 \%$ & $100.0 \%$ \\
\hline \multicolumn{4}{|c|}{ Panel D: Amount invested $[\operatorname{Ln}(£)]$ by ethnic and gender similarity } \\
\hline \multirow{2}{*}{ Gender similarity } & \multicolumn{2}{|c|}{ Ethnic similarity } & \multirow{2}{*}{ Total } \\
\hline & No & Yes & \\
\hline No & 5.43 & 5.44 & 5.43 \\
\hline Yes & 5.58 & $5.86 * *$ & $5.74 *$ \\
\hline Total & 5.53 & $5.73 *$ & 5.65 \\
\hline
\end{tabular}

* Difference in mean values with respect to the complementary groups (i.e., "no gender similarity" and "no ethnic similarity" respectively) is statistically significant at $1 \%$ level. ${ }^{* *}$ Difference in mean values with respect to the complementary groups (i.e., "neither gender nor ethnic similarity", "ethnic similarity only" and "gender similarity only") is statistically significant at $1 \%$ level.

\section{Model Specification and Variable Description}

We use ordinary least square (OLS) regressions to evaluate whether similarity patterns, in terms of ethnicity, gender and their interaction, increase the amount invested by individual investors. Specifically, we use the following specification:

$$
y_{i}=\alpha_{i}+\sum_{s=1}^{3} \beta_{s} \omega_{i}+\sum_{s=1}^{10} \beta_{s} \gamma_{i}+\varepsilon_{i},
$$

where $y$ is the natural logarithm of the amount invested by each investor during the equity crowdfunding campaign; $i$ identifies the individual investment $(i=1,2,3, \ldots, 8600) ; \beta_{s}$ are the parameters to be estimated, $\omega$ is a vector of independent variables that explicitly target the similarity between investor and founder and $\gamma$ is a vector of control variables linked to investor, founder, company and campaign characteristics. 
The standard errors are robust and clustered by investors' identification in order to control for non-independence of observations for investors across campaigns. We perform formal tests of variance inflated factor (VIF) and their results do not suggest a serious issue of multicollinearity. To capture possible temporal trends, we insert year fixed effects in all models.

\subsection{Independent Variables}

In the covariate group, we consider three variables that explicitly target the similarity between investor and founders. Specifically, the ethnic similarity effect is proxied by the variable Ethnic similarity, a dummy variable that equals 1 when investor and (at least one) founder share the same ethnicity, and 0 otherwise. The gender similarity effect is proxied by the variable Gender similarity, a dummy that equals 1 in case of gender similarity between investor and (at least one) founder, and 0 otherwise. We also include the interaction between ethnic and gender similarities-Interaction (Ethnic \& Gender similarity)—to explore the potential relationship of the two similarities.

\subsection{Control Variables}

There are several variables that can influence the investment decision process of investors, for which we have to control. Some refer to investor and founder sociodemographic characteristics, others to company features, and others to campaign structure (Table 1).

In order to control for sociodemographic characteristics of investor we introduce three dummy variables. The first one, Ethnic minority investor, is equal to 1 for investor belonging to the minority group; the second one is the dummy Female investor, a dummy variable equal to 1 for female investor and 0 otherwise. Finally, we control for investor with a prior investment experience on Crowdcube as in Mohammadi and Shafi [57]. To do that, we introduce the dummy variable Serial investor, equal to 1 for investors that have participated in more than one campaign, and 0 otherwise. Serial investors represent $29 \%$ of the total sample and the logarithm transformation of the average amount they invested is 5.09 (Table 1).

Variables related to the founder's profile deal with ethnicity and gender characteristics. The ethnic profile is captured by the variable At least one ethnic minority founder, a dummy that equals 1 if there is at least one ethnic minority founder in the company, and 0 for dominant ones. At least one female founder is a dummy variable that equals 1 for at least one woman among the founders of the company, and 0 otherwise.

Company features first refer to the sector of business, which is captured by the variable Innovative, a dummy variable that equals 1 for companies active in highly innovative sectors, on the basis of SIC codes [63], and 0 otherwise. Then, the age of the company is captured by the variable Firm age-the number of years from the firm's establishment to the date of the campaign; younger firms are riskier because they suffer from liabilities of newness and smallness and have short track records [57]. Finally, we add the variable Team size, computed as the logarithm of the number of people listed on the Crowdcube site as the group of executives and employees around the founder. A large number of team members is proportional to the number of investors and funding amount collected during the campaign $[7,40]$.

Financial Campaign structure is proxied by the following variables. Goal amount is the logarithm of the target amount in the campaign and controls for the size of the project. As the goal amount variable could produce an endogeneity bias as evidenced by Cumming et al. [64,65], we replicated our baseline estimations without this variable and results do not change. All results are available upon request to the authors.

Equity offering is the percentage of equity offered during the campaign and can be considered as a proxy for firm risk for several reasons. On one hand, signalling theory [66] indicates the manager's choice of raising equity as a negative signal for investors, since firms opportunistically choose to raise equity when managers know their shares are overvalued. Similarly, an owner's decision to offer a lower amount of equity can indicate less adverse selection risk, in that a negative outcome is less likely 
to be perceived by owners [7]. Furthermore, larger equity offerings can dilute entrepreneurs' incentive to commit to the firms involved. Altogether, more equity offering suggests that a firm is riskier [57]. Exit is a discrete variable that accounts for the number of exit strategies explicit in the campaign. A planned exit strategy influences the success of the campaign: i.e., receiving a return on the money invested. This is typically only attained through an exit or liquidity event, so the presence of different exit strategies could make a campaign more attractive [7].

As evidenced by Cumming [64], Crowdcube also offers companies the possibility of placing both Class A (carrying voting rights) and Class B (not carrying voting rights). Given the investment threshold to acquire Class A is higher compared to Class B; we expect that this variable plays an important role in the investment size decision. Moreover, further analysis developed by the authors highlights that the coexistence of both gender and ethnic similarity positively and significantly affects the decision to invest in 'A-shares'. However, including this variable in our baseline analysis could produce an endogeneity bias as evidenced by previous literature $[64,65]$. Nonetheless, we replicated our estimation considering a dummy variable for investment in A-shares (and in a sub-sample excluding A-shares investments) and results do not change. All results are available, upon request to the authors.

Note that, in the Appendix A, Table A1 shows details on variables' definition while in the Appendix B, Table A2 illustrates correlation indexes between the dependent variable (i.e., logarithm of the amount invested in a campaign), the variables of interest (i.e., similarity dummies), and all covariates included in the model specification.

\section{Results}

\subsection{Influences of Similarity on the Amount Invested}

Following the model specification overall described in Section 4, Mod. 1 and 2 of Table 3 show estimated effects of similarity on the amount invested in a single campaign for the overall sample. The estimation results of Mod. 1 highlight that ethnic similarity between investor and founder determines, ceteris paribus, a $17 \%$ increase in the amount invested, whereas gender similarity turns out to have an opposite impact $(-12 \%)$ on the dependent variable. When the interaction between similarity variables is included, Mod. 2 shows that ethnic similarity has a positive and significant role on the amount invested in a campaign only if a coexistence with a gender similarity is in place. Therefore, as a result for the whole sample: (i) the presence of ethnic similarity alone does not seem to have any effect on the amount invested; (ii) the presence of gender similarity between investor and proponent alone reduces the amount invested by $22 \%$; and (iii) the positive effect related to the coexistence of ethnic and gender similarity $(+18 \%$ in the amount invested) covers the negative effects of gender similarity, making the overall effect of similarities on the dependent variable almost null. Moreover, it is important to specify that both in Mod. 1 and Mod. 2, the similarity variables overall considered are always jointly significant at $1 \%$ level (F-Test equals 7.84 and 6.61).

Looking at estimated coefficients of covariates, most of them are in line with expectations and stable across the Models reported in Table 3. First, investors' membership of an ethnic minority group seems to significantly reduce investment size in an equity crowdfunding campaign, indicating maybe a lower '(monetary) power of investing' by this category of investors and a lower level of business-related experiences $[61,62]$. Moreover, confirming a common finding in the economic literature, results show that female investors tend to invest less than male ones ( $49 \%$ less if we consider Mod. 2). This is probably related to the fact that women generally have a higher risk aversion compared to men [67], so they may prefer to diversify investment choices or be more careful overall. To be noted, the sample used to develop this analysis consists of investors only, so that the lower propensity of women to invest, in general, cannot be revealed here except for the composition of the sample itself. Therefore, the effect of being female estimated in this analysis for investors is already conditioned by the probability of investing in any equity crowdfunding campaign, and merely refers to the number of euros invested in a campaign. 
Table 3. OLS Regression: Similarity effect by ethnicity and gender groups of investors.

\begin{tabular}{|c|c|c|c|c|c|c|}
\hline & (Mod. 1) & (Mod. 2) & (Mod. 3) & (Mod. 4) & (Mod. 5) & (Mod. 6) \\
\hline Variables & All & All & $\begin{array}{l}\text { Dominant } \\
\text { Female }\end{array}$ & $\begin{array}{l}\text { Dominant } \\
\text { Male }\end{array}$ & $\begin{array}{l}\text { Minority } \\
\text { Female }\end{array}$ & $\begin{array}{l}\text { Minority } \\
\text { Male }\end{array}$ \\
\hline Constant & $\begin{array}{c}2.272 * * * \\
(0.275)\end{array}$ & $\begin{array}{c}2.342^{* * *} \\
(0.277)\end{array}$ & $\begin{array}{c}3.099 * * * \\
(0.639)\end{array}$ & $\begin{array}{c}2.075^{* * *} \\
(0.336)\end{array}$ & $\begin{array}{l}1.168 \\
(1.606)\end{array}$ & $\begin{array}{l}1.559^{* *} \\
(0.717)\end{array}$ \\
\hline Ethnic similarity & $\begin{array}{c}0.165^{* * *} \\
(0.048)\end{array}$ & $\begin{array}{c}0.038 \\
(0.080)\end{array}$ & $\begin{array}{l}-0.143 \\
(0.145)\end{array}$ & $\begin{array}{c}-0.399 * * * \\
(0.125)\end{array}$ & $\begin{array}{c}0.303 \\
(0.371)\end{array}$ & $\begin{array}{c}1.159^{* * *} \\
(0.250)\end{array}$ \\
\hline Gender similarity & $\begin{array}{l}-0.115^{*} \\
(0.063)\end{array}$ & $\begin{array}{l}-0.216^{* * *} \\
(0.081)\end{array}$ & $\begin{array}{c}-0.753^{* * *} \\
(0.214)\end{array}$ & $\begin{array}{l}-0.040 \\
(0.102)\end{array}$ & $\begin{array}{l}-0.868^{* *} \\
(0.354)\end{array}$ & $\begin{array}{c}0.554^{* * *} \\
(0.153)\end{array}$ \\
\hline $\begin{array}{l}\text { Interaction (Ethnic \& } \\
\text { Gender similarity) }\end{array}$ & & $\begin{array}{l}0.184^{* *} \\
(0.093)\end{array}$ & $\begin{array}{c}0.125 \\
(0.275)\end{array}$ & $\begin{array}{c}0.518^{* * *} \\
(0.142)\end{array}$ & $\begin{array}{c}2.284^{* * *} \\
(0.660)\end{array}$ & $\begin{array}{c}-0.896^{* * *} \\
(0.293)\end{array}$ \\
\hline $\begin{array}{l}\text { Ethnic minority } \\
\text { investor }\end{array}$ & $\begin{array}{c}-0.150 * * * \\
(0.056)\end{array}$ & $\begin{array}{c}-0.144^{* *} \\
(0.056)\end{array}$ & & & & \\
\hline Female investor & $\begin{array}{c}-0.506^{* * *} \\
(0.064)\end{array}$ & $\begin{array}{c}-0.492 * * * \\
(0.065)\end{array}$ & & & & \\
\hline Serial investor & $\begin{array}{l}-0.726^{* * *} \\
(0.045)\end{array}$ & $\begin{array}{l}-0.725^{* * *} \\
(0.045)\end{array}$ & $\begin{array}{l}-0.391 * * \\
(0.153)\end{array}$ & $\begin{array}{l}-0.729^{* * *} \\
(0.054)\end{array}$ & $\begin{array}{c}-1.106^{* * *} \\
(0.293)\end{array}$ & $\begin{array}{c}-0.850^{* * *} \\
(0.102)\end{array}$ \\
\hline $\begin{array}{l}\text { At least one ethnic } \\
\text { minority proponent }\end{array}$ & $\begin{array}{c}0.447^{* * *} \\
(0.061)\end{array}$ & $\begin{array}{c}0.443^{* * *} \\
(0.062)\end{array}$ & & & & \\
\hline $\begin{array}{l}\text { At least one female } \\
\text { proponent }\end{array}$ & $\begin{array}{c}-0.369 * * * \\
(0.067)\end{array}$ & $\begin{array}{c}-0.377^{* * *} \\
(0.067)\end{array}$ & & & & \\
\hline Innovative & $\begin{array}{c}-0.142^{* *} \\
(0.064)\end{array}$ & $\begin{array}{l}-0.142 * * \\
(0.064)\end{array}$ & $\begin{array}{l}-0.233 \\
(0.190)\end{array}$ & $\begin{array}{l}-0.034 \\
(0.077)\end{array}$ & $\begin{array}{l}-0.070 \\
(0.441)\end{array}$ & $\begin{array}{l}-0.395^{* *} \\
(0.158)\end{array}$ \\
\hline Firm age & $\begin{array}{c}0.110 * * * \\
(0.010)\end{array}$ & $\begin{array}{c}0.110^{* * *} \\
(0.010)\end{array}$ & $\begin{array}{c}0.089 * * * \\
(0.023)\end{array}$ & $\begin{array}{c}0.109 * * * \\
(0.012)\end{array}$ & $\begin{array}{l}-0.008 \\
(0.052)\end{array}$ & $\begin{array}{c}0.120^{* * *} \\
(0.026)\end{array}$ \\
\hline Team size & $\begin{array}{l}0.099 * * \\
(0.043)\end{array}$ & $\begin{array}{l}0.110^{* *} \\
(0.044)\end{array}$ & $\begin{array}{c}0.128 \\
(0.125)\end{array}$ & $\begin{array}{c}0.175^{* * *} \\
(0.056)\end{array}$ & $\begin{array}{l}-0.022 \\
(0.336)\end{array}$ & $\begin{array}{c}0.160 \\
(0.115)\end{array}$ \\
\hline Goal amount & $\begin{array}{c}0.321^{* * *} \\
(0.022)\end{array}$ & $\begin{array}{c}0.320^{* * *} \\
(0.022)\end{array}$ & $\begin{array}{l}0.229^{* * *} \\
(0.053)\end{array}$ & $\begin{array}{c}0.321^{* * *} \\
(0.028)\end{array}$ & $\begin{array}{l}0.431^{* * *} \\
(0.127)\end{array}$ & $\begin{array}{c}0.323^{* * *} \\
(0.062)\end{array}$ \\
\hline Equity offering & $\begin{array}{c}-0.859 * * * \\
(0.264)\end{array}$ & $\begin{array}{c}-0.842 * * * \\
(0.264)\end{array}$ & $\begin{array}{c}0.292 \\
(0.830)\end{array}$ & $\begin{array}{l}-0.386 \\
(0.315)\end{array}$ & $\begin{array}{l}-2.253 \\
(1.708)\end{array}$ & $\begin{array}{c}-1.156^{*} \\
(0.682)\end{array}$ \\
\hline Exit & $\begin{array}{c}0.056 \\
(0.040)\end{array}$ & $\begin{array}{c}0.056 \\
(0.040)\end{array}$ & $\begin{array}{l}0.105 \\
(0.110)\end{array}$ & $\begin{array}{c}0.043 \\
(0.050)\end{array}$ & $\begin{array}{l}-0.210 \\
(0.334)\end{array}$ & $\begin{array}{c}0.124 \\
(0.094)\end{array}$ \\
\hline Year fixed effect & Yes & Yes & Yes & Yes & Yes & Yes \\
\hline $\begin{array}{l}\text { F-test (Similarity } \\
\text { variables) }\end{array}$ & $7.84^{* * *}$ & $6.61^{* * *}$ & $7.97^{* * *}$ & $8.48^{* * *}$ & $7.84^{* * *}$ & $9.84^{* * *}$ \\
\hline Observations & 8.600 & 8.600 & 1.336 & 5.696 & 267 & 1.301 \\
\hline R-squared & 0.122 & 0.123 & 0.125 & 0.109 & 0.254 & 0.165 \\
\hline Adj. R-squared & 0.120 & 0.121 & 0.117 & 0.107 & 0.215 & 0.156 \\
\hline
\end{tabular}

Notes: Dependent variables: log of amount invested by individual investor. Robust standard errors in parentheses. $* * * * *$ and ${ }^{*}$ indicates statistical significance at the $1 \%, 5 \%$ and $10 \%$, respectively. Models $3-6$ do not include dummies for gender and ethnicity of both investors and proponents to avoid the perfect collinearity issue. For a description of the variables, see Table A1 in the Appendix A.

Furthermore, the negative and significant coefficient of the serial investors' dummy confirms the descriptive statistics, pointing to a lower amount invested due to the high frequency of investments. This investment behavior, common for all columns of Table 3 (i.e., regardless of the ethnic and gender origin of the investors), seems to suggest more a gambling strategy than a genuine interest in the campaign.

As for control variables related to the founder's profile, estimation results in Table 3 (Mod. 1 and 2) show that the amount invested increases by $44 \%$ if the campaign has a founder belonging to an ethnic minority group and, conversely, the amount invested decreases by about $37 \%$ if the campaign has at least one female founder. All variables reporting company features clearly play an important role in investment size decision. In particular, the amount invested in equity crowdfunding campaigns is higher for older companies, while being innovative appears to decrease the amount invested. In line with Vismara [11] and Ahlers et al. [7], larger teams attract higher invested amounts. Finally, as regards 
to covariates related to the campaign structures, investors report, ceteris paribus, a greater amount invested when the goal amount is higher and when the share of equity offered is lower, whereas the positive sign related to the exit strategy is not statistically significant. In conclusion, as expected, the level of amount invested changes according to campaign and company features, but investors' and founders' characteristics turn out to have an overwhelming role.

Estimates reported in Mod. 2 of Table 3 highlight that the overall effect of similarities on the dependent variable is almost null in the case of coexistence of ethnic and gender similarity; however, this finding may be related to important differences within the group of investors analyzed. For this reason, we also decide to explore whether potential similarity effects are heterogeneous by the ethnicity and gender of investors. Results in Mod. 3-6 show estimates from a combination of ethnic and gender groups of investors: female/male investors belonging to dominant ethnic groups (Mod. 3 and 4) and female/male investors belonging to minority ethnic groups (Mod. 5 and 6). With regard to ethnic similarity, results show that it does not significantly affect female investors (Mod. 3 and 5), and it produces divergent effects on male ones (Mod. 4 and 6). In fact, male investors belonging to the dominant ethnicity tend to invest a smaller amount of money (specifically $40 \%$ less) in an equity crowdfunding campaign in the case of ethnic similarity with at least one proponent, while the opposite occurs (i.e., $+116 \%$ in the amount invested) for male investors belonging to an ethnic minority group. Turning to the gender similarity, it has positive effects on the amount invested in a campaign among male investors belonging to an ethnic minority (Mod. 6), whereas it has a negative effect on female investors varying between $-75 \%$ and $-87 \%$ according to their ethnicity (Mod. 3 and 5 ).

Finally, estimated results for the interaction term allow us to provide three further interesting findings. First, the coexistence of similarity patterns positively influences the investment size for male investors belonging to the dominant ethnicity and for female investors belonging to an ethnic minority (Mod. 4 and 5). In both cases, the positive impacts of the similarities' coexistence (respectively, $+52 \%$ for males and $+228 \%$ for females) overpass, in magnitude, the negative ones coming from single similarities. This means that the overall effect of similarity on the amount invested is positive and equals to about $+8 \%$ for male investors belonging to the dominant ethnicity and to about $+172 \%$ for female investors belonging to an ethnic minority.

Second, when we consider male investors belonging to an ethnic minority group (Mod. 6), the coexistence of ethnic and gender similarity is, instead, negative and seems to moderate the joint positive effect of similarities on the amount invested. Nonetheless the overall effect of similarity on the investment size remains the second highest one (i.e., $+82 \%$ ) among the four subcategories analyzed. Third, the effect of similarities' coexistence is insignificant for female investors belonging to the dominant ethnicity, which thus represent only one category of investors reporting a similarity effect overall negative $(-77 \%)$ on the amount invested.

In conclusion, as regards to $\mathrm{H} 1 \mathrm{a}$ and $\mathrm{H} 1 \mathrm{~b}$, similarity patterns seem to significantly influence the amount invested in a campaign, but their effects change according to investors' ethnicity and gender. Moreover, the coexistence of different homophily patterns (ethnicity and gender) between investor and founder boosts the amount invested by the single investor, thus indicating the existence of a cumulative effect of similarity patterns (H2), except for the subsample of female investors belonging to the dominant minority group.

\subsection{A Shapley Decomposition Analysis of Drivers}

The analysis presented in the previous section, grounded on the OLS regression method, provides the impact (in terms of both extent and statistical significance) of each variable on the amount invested in an equity crowdfunding campaign, but it does not allow us to understand their relative importance in our model specification. In other words, it is not possible to rank the variable effects on the investment decision process. To better identify their concurring role in investment size, we investigate the importance and relative effects of the different independent variables on the logarithm of the amount invested per campaign. In our model specification, it is possible to distinguish between five 
groups of variables: (i) similarity (i.e., one dummy for each type of similarity and their interaction term); (ii) investor characteristics (i.e., sociodemographic variable on investors' gender and ethnicity, and seriality); (iii) founder characteristics (i.e., sociodemographic variables for proponents' gender and ethnicity); (iv) company characteristics (i.e., variables for innovative sector of activity, firm age, and team size); and (v) campaign characteristics (i.e., variables for goal amount, equity offering and exit strategy).

To estimate the explanatory power of the independent variables, we refer to the Shapley decomposition method [30] which allows the goodness-of-fit measure of an econometric model to be distributed among regressors. As a goodness-of-fit measure, we adopt the total R2-value obtained from the OLS estimations of Mod. 2-6 of Table 3. Since some attributes consist of groups of variables, we use a generalization of the Shapley value, the Owen value [68], for decomposition in the case of exogenously grouped regressors, as suggested by Shorrocks [69]. Results of the Shapley and Owen decomposition methods are reported in Table 4.

As expected, being a serial investor plays an important role in explaining heterogeneity in the amount invested during the campaign, since about $29 \%$ of the R-squared for total sample (Mod. 2) depends on this single variable. Decomposition results also underline the pivotal role that campaign and company characteristics have on the amount invested, which is nearly exclusively related to the goal amount for the campaign and on the company's age and team size for the company. Regarding the remaining variables, the overall R-squared for the full sample can be explained mainly by two groups of characteristics: founder profile, which is linked to the presence of at least one female founder in the company; and the dummies referring to similarity patterns between investor and founders, as well as their interaction term. Since the latter has the highest explanatory power among the group of 'similarity variables', this finding further confirms the role of the coexistence of ethnic and gender similarities also in determining investment size variability.

As in the previous analysis, we disaggregate our sample by investors' gender and ethnic origin. Table 4 highlights that female and male investors look at different aspects when deciding how much to invest in a campaign. Investors' characteristics play the most important role in explaining the heterogeneity of the investment sizes for male investors, independently of ethnicity, probably because of their higher propensity to gamble [70] (Table 4, Mod. 4 and 6), while female investors attach more importance to company characteristics and to team size (Table 4, Mod. 3 and 5).

Differences between female and male investors also emerge for the group of similarity variables. For female investors, similarity variables represent the second most important group of variables in explaining the heterogeneity of investment sizes (Table 4, Mod. 3 and 5) while male investors attach less importance-nearly half-to these homophily patterns (Table 4, Mod. 4 and 6). It is worth noting that for female investors, important differences emerge between dominant and ethnic minority. In particular, for female investors belonging to the dominant ethnic group, the similarity variables account for nearly $28 \%$ of the overall R-squared (Table 4, Mod. 3), given the role played by the gender similarity variable. In contrast, the interaction term representing the coexistence of the two similarity patterns (ethnicity and gender) appears to play a primary role for female investors belonging to an ethnic minority group, showing almost the same explanatory power as the team size (Table 4, Mod. 5). 
Table 4. Shapley and Owen value decomposition of R-squared by investors' characteristics.

\begin{tabular}{|c|c|c|c|c|c|c|c|c|c|c|c|}
\hline \multirow{3}{*}{ Groups } & \multirow{3}{*}{ Variables } & \multicolumn{2}{|c|}{ (Mod. 2) Total sample } & \multicolumn{2}{|c|}{$\begin{array}{c}\text { (Mod. 3) } \\
\text { Dominant Female }\end{array}$} & \multicolumn{2}{|c|}{ (Mod. 4) Dominant Male } & \multicolumn{2}{|c|}{$\begin{array}{c}\text { (Mod. 5) } \\
\text { Minority Female }\end{array}$} & \multicolumn{2}{|c|}{ (Mod. 6) Minority Male } \\
\hline & & Ind. $\%$ & Group \% & Ind. $\%$ & Group \% & Ind. $\%$ & Group \% & Ind. $\%$ & Group \% & Ind. $\%$ & Group \% \\
\hline & & R-Squared & R-Squared & R-Squared & R-Squared & R-Squared & R-Squared & R-Squared & R-Squared & R-Squared & R-Squared \\
\hline \multirow{3}{*}{ Similarity } & Ethnic similarity & 1.01 & 4.45 & 0.54 & 28.39 & 1.52 & 10.02 & 3.49 & 27.81 & 2.82 & 14.28 \\
\hline & Gender similarity & 1.27 & & 19.46 & & 3.34 & & 4.08 & & 9.25 & \\
\hline & $\begin{array}{l}\text { Interaction (Ethnic and } \\
\text { Gender similarity) }\end{array}$ & 2.18 & & 8.39 & & 5.16 & & 20.25 & & 2.21 & \\
\hline \multirow{3}{*}{$\begin{array}{c}\text { Investor } \\
\text { characteristics }\end{array}$} & Ethnic minority investor & 1.44 & 35.92 & & & & & & & & \\
\hline & Female investor & 5.44 & & & & & & & & & \\
\hline & Serial investor & 29.03 & & 5.43 & 5.43 & 36.17 & 36.17 & 23.00 & 23.00 & 39.00 & 39.00 \\
\hline \multirow{2}{*}{$\begin{array}{c}\text { Founder } \\
\text { characteristics }\end{array}$} & $\begin{array}{c}\text { At least one } \\
\text { ethnic minority founder }\end{array}$ & 0.74 & 8.22 & & & & & & & & \\
\hline & $\begin{array}{l}\text { At least one female } \\
\text { founder }\end{array}$ & 7.48 & & & & & & & & & \\
\hline \multirow{3}{*}{$\begin{array}{c}\text { Company } \\
\text { characteristics }\end{array}$} & Innovative & 1.19 & 24.88 & 3.13 & 40.07 & 0.27 & 21.52 & 5.15 & 28.92 & 3.90 & 24.73 \\
\hline & Firm age & 13.16 & & 7.73 & & 15.50 & & 2.61 & & 11.11 & \\
\hline & Team size & 10.53 & & 29.21 & & 5.75 & & 21.17 & & 9.72 & \\
\hline \multirow{3}{*}{$\begin{array}{c}\text { Campaign } \\
\text { characteristics }\end{array}$} & Goal amount & 23.64 & 26.53 & 20.28 & 26.11 & 29.58 & 32.30 & 15.19 & 20.27 & 17.15 & 21.99 \\
\hline & Equity offering & 0.70 & & 0.37 & & 0.92 & & 1.22 & & 1.58 & \\
\hline & Exit & 2.18 & & 5.47 & & 1.81 & & 3.86 & & 3.26 & \\
\hline
\end{tabular}

Note: This table reports the fraction of the overall R-squared (per cent), explained by the different groups of characteristics—Owen value (Gr)—and the individual share (Ind) of the overall $\mathrm{R}$-squared (per cent) associated with each variable belonging to a specific characteristic (Shapley decomposition). These shares are median values within bootstrap percentile confidence intervals (level of confidence: $90 \%$ ). This explains cases where Total is not always 100.00. Year fixed effects are not considered in Models. For a description of the variables, see Table A1 in the Appendix A. 


\subsection{Robustness Checks}

Both the OLS regression estimates and the Shapley decomposition analysis highlighted the large importance of investment seriality in describing the amount invested, and its dynamics, in equity crowdfunding campaigns. To test whether the peculiar behavior adopted by serial investors influences our results, here we present a robustness check where serial investors are included just once (i.e., only their first investment is considered) in the sample of investments. Tables 5 and 6 report results of the same analysis, illustrated in Sections 5.1 and 5.2, for a sample with this serial investor adjustment.

Table 5. Similarity effects with serial investors' adjustment.

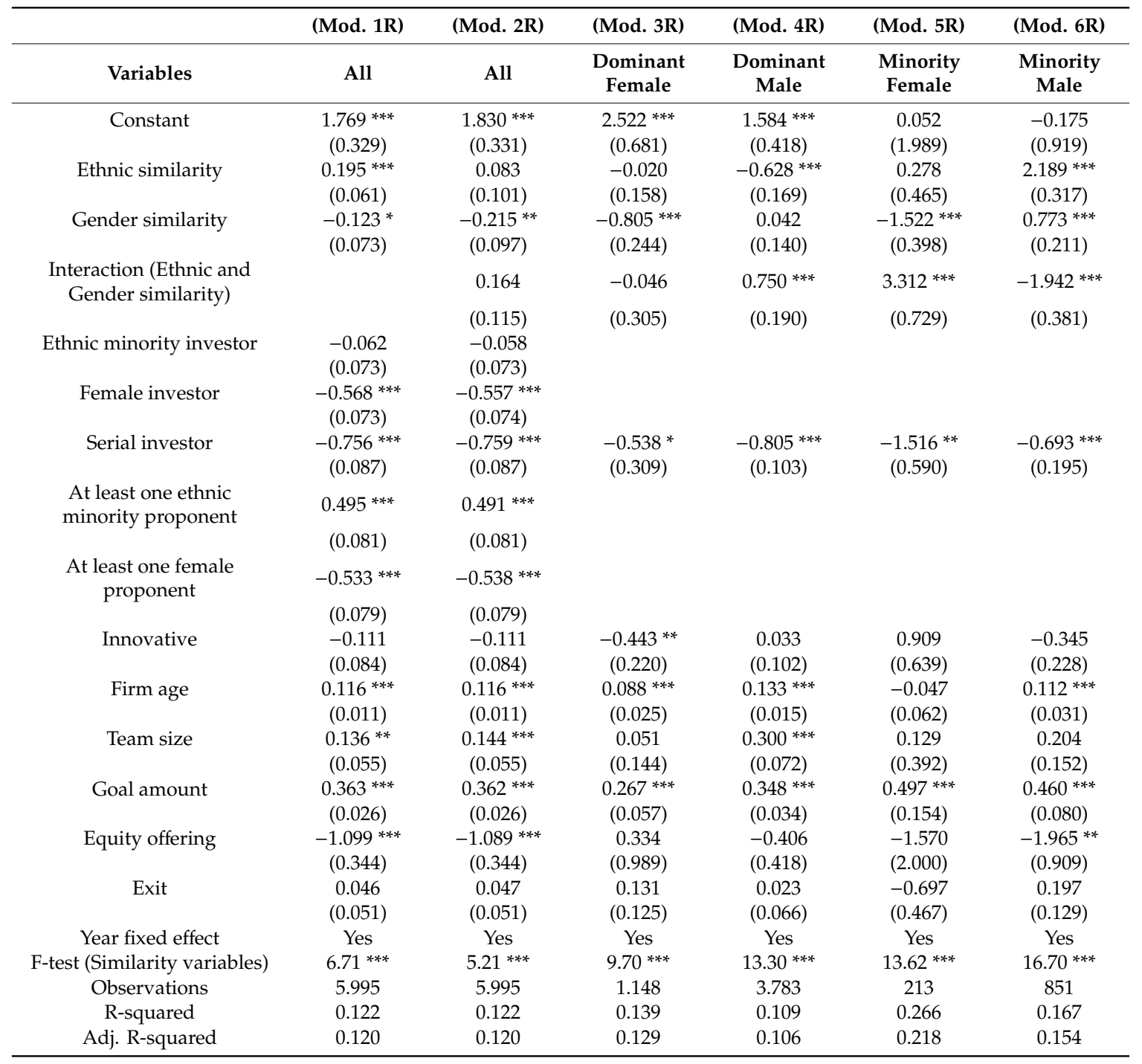

Note: Dependent variables: log of amount invested by individual investor. Robust standard errors in parentheses. $* * *, * *$ and * indicates statistical significance at the $1 \%, 5 \%$ and $10 \%$, respectively. Models 3-6 do not include dummies for gender and ethnicity of both investors and proponents to avoid the perfect collinearity issue. For a description of the variables, see Table A1 in the Appendix A. 
Table 6. Shapley and Owen value decomposition of R-squared by investors' characteristics with serial investors' adjustment.

\begin{tabular}{|c|c|c|c|c|c|c|c|c|c|c|c|}
\hline \multirow{3}{*}{ Groups } & \multirow{3}{*}{ Variables } & \multicolumn{2}{|c|}{ (Mod. 2R) Total Sample } & \multicolumn{2}{|c|}{$\begin{array}{c}\text { (Mod. 3R) } \\
\text { Dominant Female }\end{array}$} & \multicolumn{2}{|c|}{$\begin{array}{c}\text { (Mod. 4R) } \\
\text { Dominant Male }\end{array}$} & \multicolumn{2}{|c|}{$\begin{array}{c}\text { (Mod. 5R) } \\
\text { Minority Female }\end{array}$} & \multicolumn{2}{|c|}{$\begin{array}{c}\text { (Mod. 6R) } \\
\text { Minority Male }\end{array}$} \\
\hline & & Ind. $\%$ & Group \% & Ind. $\%$ & Group \% & Ind. $\%$ & Group \% & Ind. $\%$ & Group \% & Ind. $\%$ & Group \% \\
\hline & & R-Squared & R-Squared & R-Squared & R-Squared & R-Squared & R-Squared & R-Squared & R-Squared & R-Squared & R-Squared \\
\hline \multirow{3}{*}{ Similarity } & Ethnic similarity & 0.95 & & 0.51 & & 2.01 & & 6.01 & & 11.65 & \\
\hline & Gender similarity & 1.96 & 5.17 & 20.26 & 31.45 & 6.42 & 15.57 & 9.49 & 50.84 & 11.52 & 31.19 \\
\hline & $\begin{array}{l}\text { Interaction (Ethnic and } \\
\text { Gender similarity) }\end{array}$ & 2.26 & & 10.68 & & 7.14 & & 35.33 & & 8.02 & \\
\hline \multirow{3}{*}{$\begin{array}{c}\text { Investor } \\
\text { characteristics }\end{array}$} & Ethnic minority investor & 0.40 & & & & & & & & & \\
\hline & Female investor & 9.56 & 17.63 & & 0.82 & & 12.29 & & 4.33 & & 7.23 \\
\hline & Serial investor & 7.66 & & 0.82 & & 12.29 & & 4.33 & & 7.23 & \\
\hline \multirow{2}{*}{$\begin{array}{c}\text { Founder } \\
\text { characteristics }\end{array}$} & $\begin{array}{l}\text { At least one ethnic } \\
\text { minority founder }\end{array}$ & 1.34 & 13.77 & & & & & & & & \\
\hline & $\begin{array}{l}\text { At least one female } \\
\text { founder }\end{array}$ & 12.43 & & & & & & & & & \\
\hline \multirow{3}{*}{$\begin{array}{c}\text { Company } \\
\text { characteristics }\end{array}$} & Innovative & 1.25 & & 5.51 & & 0.21 & & 0.86 & & 2.01 & \\
\hline & Firm age & 17.20 & 28.83 & 7.87 & 39.19 & 24.48 & 29.27 & 1.38 & 23.43 & 10.59 & 21.94 \\
\hline & Team size & 10.37 & & 25.81 & & 4.58 & & 21.20 & & 9.34 & \\
\hline \multirow{3}{*}{$\begin{array}{c}\text { Campaign } \\
\text { characteristics }\end{array}$} & Goal amount & 30.65 & & 21.97 & & 38.92 & & 15.16 & & 31.31 & \\
\hline & Equity offering & 1.36 & 34.60 & 0.48 & 28.54 & 1.96 & 42.87 & 1.01 & 21.39 & 3.42 & 39.64 \\
\hline & Exit & 2.59 & & 6.08 & & 1.99 & & 5.22 & & 4.92 & \\
\hline
\end{tabular}

Note: This table reports the fraction of the overall R-squared (per cent), explained by the different groups of characteristics—Owen value (Gr)—and the individual share (Ind) of the overall $\mathrm{R}$-squared (per cent) associated with each variable belonging to a specific characteristic (Shapley decomposition). These shares are median values within bootstrap percentile confidence intervals (level of confidence: $90 \%$ ). This explains cases where Total is not always 100.00 . Year fixed effects are not considered in Models. For a description of the variables, see Table A1 in the Appendix A. 
The main findings remain qualitatively the same and the overall stability of the estimated coefficients confirms the robustness of our results. Only a few differences are worth mentioning. As for the OLS regression analysis, Table 5 shows that variables related to the interaction of the two similarities and to investor ethnicity lose their statistical significance (Mod. 2R). This happens only for the entire sample, while for the subsamples analyzed, our results are robust to the serial investor adjustment, once more highlighting the heterogeneity that affects our groups of investors.

As for the Shapley decomposition analysis, as expected, Table 6 shows that individual and group shares of R-squared, presented by similarity dummies and other covariates, increase when the adjustment for serial investors is considered. This increase particularly involves the role of similarity dummies across the six different Models analyzed, explaining more than one third of the investment size heterogeneity among the various groups of investors, except for male investors belonging to the dominant group (Table 6, Mod. 4R).

Moreover, among the similarity group of variables, the gender similarity dummy plays a primary role in the explained variance of the dependent variable, except for the case of female investors belonging to an ethnic minority (Table 6, Mod. 5R), where the interaction of ethnic and gender similarity variable is the most important. It is worth underlining that the ethnic similarity variable shows the highest value for male investors belonging to an ethnic minority group (Table 6, Mod. 6R).

Although the main results of our analysis remain the same overall, we prefer to consider the sample with the serial investor adjustment as a robustness check only. In fact, the lower number of observations may lead to more unstable estimates, especially when similarity effects by gender and ethnicity groups of investors are observed.

\section{Discussion}

This study identifies whether and how the ethnic and gender similarity among founder and investor affects the invested amount in an equity crowdfunding campaign. The results show that similarity, in terms of both ethnic and gender matching, conditions the level of amount invested, but its effects change according to investors' characteristics. Particularly, unlike previous studies [29,33], our work evidences that in equity crowdfunding, female investors show a clear preference to invest a higher amount in men-led campaigns. Nevertheless, female founders belonging to an ethnic minority group receive significant amount from female investors sharing the same ethnic origin. For male investors, the level of amount invested in the campaign is higher if they have the same ethnic minority profile as the founder. We find that similarity in equity crowdfunding, seems to enlarge the potential funding sources for founders belonging to an ethnic minority group. Consistent with Butticè and Useche [27], crowdfunding offers ethnic minority entrepreneurs an effective setting to activate external networks to collect financial resources. An ethnic match, especially for ethnic minority groups, compensates other campaign aspects, such as team size and the presence of an exit strategy. For ethnic minority female investors, the level of amount invested in the campaign is favored by the coexistence of ethnic and gender similarity patterns. Consistent with the homophily literature, we conclude that gender and ethnic similarities between investor and founder, as well as any of their combinations, also significantly affect the variability of the amount invested in equity crowdfunding campaigns, whereas a lower importance appeared to be associated to financial characteristics.

By combining both ethnic and gender similarity, at first, we contribute to the study about similarity patterns between investor and founder as a driver of investment decisions for new venture ideas (e.g., $[23,25,29])$. In the online context, ethnic similarity strengthens the network mechanisms that underlie crowdfunding to harness communities of investors, improving solidarity, mobilizing ethnic groups and overcoming barriers in relation to access to finance [27]. Ethnicity is often a basis for differential acculturation, which shapes values and personal identity. Ethnic similarity entails a broad range of cultural aspects that combine to create a group-level identity able to overcome other individual identity characteristics, and thus, the perception of common barriers faced. Due to ethnic solidarity, 
investors tend to support businesses led by immigrant groups concentrated in a distinct spatial location and which serve their own ethnic market and/or the general population [71,72].

Secondly, in the field of equity crowdfunding studies, we contribute new insights to the emerging research on crowd investors (e.g., [31,32]) by showing that the level of amount invested is driven not only by financial motivations, but also by founders' and investors' sociodemographic characteristics. As highlighted by Polzin et al. [73], a better understanding of crowd investor characteristics reduces ex-ante search costs and facilitates ex-post matching. Our results highlight that the coexistence of similarity patterns in the investment decision process is particularly strong for female investors belonging to an ethnic minority group. From the seekers' perspective, our study allows women and ethnic minority entrepreneurs to identify the investor behaviors and characteristics that maximize fund raising opportunities through equity crowdfunding campaigns. From the suppliers' perspective, we identify how women and ethnic minorities perceive and invest in equity crowdfunding projects, thus contributing to theory building.

Finally, we contribute to the nascent literature on equity crowdfunding as a tool for supporting financial inclusion. Financial inclusion is, in fact, defined as a state in which individuals or firms have access to financial products and services appropriate to their needs [74-76] or as a multi-dimensional process which requires three dimensions to be financially inclusive: accessibility, availability and usage [77]. In our study, equity crowdfunding appears to be a fintech tool for the sustainable financial inclusion of ethnic minorities in the financial system, for both seekers and suppliers of capital. For investors, equity crowdfunding increases the pool of potential opportunities to invest in entrepreneurial projects allowing a faster, cheaper, more transparent and more efficient access to financial services. For ethnic minority entrepreneurs, increased access to a new stream of investors means the availability of capital and the opportunity to overcome market financial constraints.

From a practical perspective, our results are relevant not only for ethnic minorities and females but for all entrepreneurs, investors, and crowdfunding platforms alike, as understanding crowd composition and investment dynamics are in the interest of all groups. Such knowledge may boost fundraising opportunities for crowdfunding proponents, especially for equity models. Therefore, female and ethnic minority entrepreneurs can figure out how to overcome the financial barriers encountered when pursuing their entrepreneurial goals [78]. For policy, the importance of fostering mutual understanding between crowdfunding and ethnic minority businesses by improving engagement and information flows, has to be emphasized through programs of action learning, intended to enable entrepreneurs of various ethnic backgrounds to appreciate this new entrepreneurial finance tool. Regulators in emerging and developing economies should also promote this inclusive financial innovation through the implementation of innovative regulatory initiatives that are explicitly targeting and delivered in a responsible way, thereby directly impacting financial inclusion $[79,80]$.

Our research has some limitations but, as a result, also suggests promising directions for future research. This study focuses on two sociodemographic factors at the basis of similarity-ethnicity and gender; in the future, other multiple similarity patterns such as age, need similarity, and value similarity should be investigated. In our study, we do not examine the content of pictures, video and descriptions published in the campaign with respect to the level of proponent's attractiveness and charisma or language adopted. Another important aspect that could reinforce similarity as a driver of investment decision in the crowdfunding context, is the business sector, as pointed out by Greenberg and Mollick [29]. Investors in crowdfunding take into account not only tangible benefits but also societal ones and studies evidence the importance of sustainable orientation of the business in reaching the funding goal and in attracting backers [64,81-85]. Future work should be directly addressed to the evaluation of whether and how ethnic and gender similarity affect the investment size in case of business characterized by different sustainable orientation. 
Author Contributions: Conceptualization, V.V. and A.P.; Formal analysis, V.V. and G.G.; Investigation, V.V. and A.P.; Methodology, V.V. and G.G.; Supervision, V.V.; Writing-Original draft, V.V., A.P. and G.G. All authors have read and agreed to the published version of the manuscript.

Funding: This research received no external funding.

Acknowledgments: Special thanks to Mustafa Caglayan, who supported us with detailed observations and comments on methodology and empirical models. We are also grateful to Evila Piva for insightful discussions and suggestions; and all the participants at the sessions where a preliminary version of the paper was presented: 2 nd Emerging Trends in Entrepreneurial Finance Conference-New York; 3rd ENTFIN Conference 2018-Milan, and 2nd European Alternative Finance Research Conference.

Conflicts of Interest: The authors declare no conflict of interest.

\section{Appendix A}

Table A1. Variables—name and description.

\begin{tabular}{|c|c|}
\hline Variable & Description \\
\hline Amount invested & $\begin{array}{l}\text { Natural logarithm of the amount invested by each investor during the } \\
\text { equity crowdfunding campaign }\end{array}$ \\
\hline Ethnic similarity & $\begin{array}{c}\text { Dummy variable that equals } 1 \text { when investor and (at least one) founder } \\
\text { share the same ethnicity, and } 0 \text { otherwise }\end{array}$ \\
\hline Gender similarity & $\begin{array}{c}\text { Dummy variable that equals } 1 \text { when investor and (at least one) founder } \\
\text { share the same gender, and } 0 \text { otherwise }\end{array}$ \\
\hline $\begin{array}{l}\text { Interaction (Ethnic and } \\
\text { Gender similarity) }\end{array}$ & $\begin{array}{l}\text { Dummy variable that equals } 1 \text { when investor and (at least one) founder } \\
\text { share the same ethnicity and the same gender, and } 0 \text { otherwise }\end{array}$ \\
\hline Ethnic minority investor & $\begin{array}{c}\text { Dummy variable that equals } 1 \text { when investor belongs to the minority } \\
\text { group, and } 0 \text { otherwise }\end{array}$ \\
\hline Female investor & Dummy variable that equals 1 for female investors, and 0 otherwise \\
\hline Serial investor & $\begin{array}{c}\text { Dummy variable that equals } 1 \text { for investor that have participated in } \\
\text { more than one campaign, and } 0 \text { otherwise }\end{array}$ \\
\hline $\begin{array}{l}\text { At least one ethnic } \\
\text { minority founder }\end{array}$ & $\begin{array}{c}\text { Dummy variable that equals } 1 \text { if there is at least one ethnic minority } \\
\text { founder in the company, and } 0 \text { otherwise }\end{array}$ \\
\hline At least one female founder & $\begin{array}{l}\text { Dummy variable that equals } 1 \text { if there is at least one woman among the } \\
\text { founders of the company, and } 0 \text { otherwise }\end{array}$ \\
\hline Innovative & $\begin{array}{c}\text { Dummy variable that equals } 1 \text { for companies active in highly innovative } \\
\text { sectors, and } 0 \text { otherwise }\end{array}$ \\
\hline Firm age & $\begin{array}{l}\text { Number of years from the firm's establishment to the date of } \\
\text { the campaign }\end{array}$ \\
\hline Team size & $\begin{array}{l}\text { Logarithm of the number of people listed on the Crowdcube site as the } \\
\text { group of executives and employees around the founder }\end{array}$ \\
\hline Goal amount & Logarithm of the campaign target amount \\
\hline Equity offering & Percentage of equity offered during the campaign \\
\hline Exit & Number of exit strategies explicit in the campaign \\
\hline
\end{tabular}




\section{Appendix B}

Table A2. Correlation matrix.

\begin{tabular}{|c|c|c|c|c|c|c|c|c|c|c|c|c|c|c|c|}
\hline Variables & 1 & 2 & 3 & 4 & 5 & 6 & 7 & 8 & 9 & 10 & 11 & 12 & 13 & 14 & 15 \\
\hline 1. Amount invested & 1.000 & & & & & & & & & & & & & & \\
\hline 2. Ethnic similarity & 0.051 & 1.000 & & & & & & & & & & & & & \\
\hline 3. Gender similarity & 0.071 & 0.052 & 1.000 & & & & & & & & & & & & \\
\hline $\begin{array}{l}\text { 4. Interaction (Ethnic and } \\
\text { Gender similarity) }\end{array}$ & 0.087 & 0.712 & 0.559 & 1.000 & & & & & & & & & & & \\
\hline 5. Ethnic minority investor & -0.046 & -0.325 & -0.007 & -0.252 & 1.000 & & & & & & & & & & \\
\hline 6. Female investor & -0.057 & 0.031 & -0.434 & -0.262 & -0.020 & 1.000 & & & & & & & & & \\
\hline 7. Serial investor & -0.178 & -0.055 & 0.021 & -0.016 & 0.022 & -0.163 & 1.000 & & & & & & & & \\
\hline $\begin{array}{l}\text { 8. At least one ethnic } \\
\text { minority founder }\end{array}$ & -0.018 & -0.363 & -0.077 & -0.278 & 0.040 & -0.010 & 0.043 & 1.000 & & & & & & & \\
\hline 9. At least one female founder & -0.107 & -0.115 & -0.545 & -0.323 & 0.028 & 0.044 & 0.041 & 0.066 & 1.000 & & & & & & \\
\hline 10. Innovative & -0.032 & 0.007 & 0.026 & 0.006 & -0.022 & 0.011 & 0.040 & -0.027 & -0.094 & 1.000 & & & & & \\
\hline 11. Firm age & 0.131 & 0.033 & 0.028 & 0.073 & 0.002 & -0.006 & -0.067 & -0.194 & -0.034 & 0.005 & 1.000 & & & & \\
\hline 12. Team size & -0.096 & 0.004 & -0.087 & -0.100 & 0.033 & 0.043 & -0.020 & 0.135 & 0.085 & 0.095 & -0.340 & 1.000 & & & \\
\hline 13. Goal amount & 0.149 & -0.033 & -0.004 & -0.042 & 0.005 & 0.104 & -0.168 & 0.019 & -0.100 & 0.003 & -0.083 & 0.241 & 1.000 & & \\
\hline 14. Equity offering & -0.018 & -0.098 & 0.007 & -0.069 & -0.019 & -0.034 & 0.049 & 0.265 & -0.023 & -0.191 & -0.260 & -0.020 & 0.159 & 1.000 & \\
\hline 15. Exit & 0.006 & -0.001 & -0.007 & -0.030 & -0.011 & 0.008 & 0.053 & 0.056 & -0.039 & 0.146 & -0.186 & 0.498 & 0.209 & 0.061 & 1.000 \\
\hline
\end{tabular}

Note: For a description of the variables, see Table A1 in the Appendix A. 


\section{References}

1. Cumming, D.; Groh, A.P. Entrepreneurial finance: Unifying themes and future directions. J. Corp. Financ. 2018. [CrossRef]

2. Barasinska, N.; Schäfer, D. Is Crowdfunding Different? Evidence on the Relation between Gender and Funding Success from a German Peer-to-Peer Lending Platform. Ger. Econ. Rev. 2014, 15, 436-452. [CrossRef]

3. Bruton, G.; Khavul, S.; Siegel, D.; Wright, M. New financial alternatives in seeding entrepreneurship: Microfinance, crowdfunding, and peer-to-peer innovations. Entrep. Theory Pract. 2015. [CrossRef]

4. Mollick, E.; Robb, A. Democratizing Innovation and Capital Access: The Role of Crowdfunding. Calif. Manage. Rev. 2016. [CrossRef]

5. Jenik, I.; Timothy, L.; Nava, A. Crowdfunding and Financial Inclusion. Cgap (Consultative Group to Assist the Poor) Working Paper. 2017. Available online: https://www.cgap.org/sites/default/files/Working-PaperCrowdfunding-and-Financial-Inclusion-Mar-2017.pdf (accessed on 22 July 2019).

6. Cumming, D.; Meoli, M.; Vismara, S. Does equity crowdfunding democratize entrepreneurial finance? Small Bus. Econ. 2019. [CrossRef]

7. Ahlers, G.K.C.; Cumming, D.; Günther, C.; Schweizer, D. Signaling in Equity Crowdfunding. Entrep. Theory Pract. 2015, 39, 955-980. [CrossRef]

8. Butticè, V.; Colombo, M.G.; Wright, M. Serial Crowdfunding, Social Capital, and Project Success. Entrep. Theory Pract. 2017, 41, 183-207. [CrossRef]

9. Fernandez-Blanco, A.; Villanueva-Balsera, J.; Rodriguez-Montequin, V.; Moran-Palacios, H. Key factors for project crowdfunding success: An empirical study. Sustainability 2020, 12, 599. [CrossRef]

10. Liang, X.; Hu, X.; Jiang, J. Research on the effects of information description on crowdfunding success within a sustainable economy-the perspective of information communication. Sustainability 2020, 12, 650. [CrossRef]

11. Vismara, S. Equity retention and social network theory in equity crowdfunding. Small Bus. Econ. 2016, 46, 579-590. [CrossRef]

12. Vulkan, N.; Åstebro, T.; Sierra, M.F. Equity crowdfunding: A new phenomena. J. Bus. Ventur. Insights 2016. [CrossRef]

13. Cholakova, M.; Clarysse, B. Does the Possibility to Make Equity Investments in Crowdfunding Projects Crowd Out Reward-Based Investments? Entrep. Theory Pract. 2015, 39, 145-172. [CrossRef]

14. Gerber, E.M.; Hui, J. Crowdfunding: Motivations and deterrents for participation. ACM Trans. Comput. Interact. 2013. [CrossRef]

15. Ordanini, A.; Miceli, L.; Pizzetti, M.; Parasuraman, A. Crowd-funding: Transforming customers into investors through innovative service platforms. J. Serv. Manag. 2011, 22, 443-470. [CrossRef]

16. Hornuf, L.; Schwienbacher, A. Market mechanisms and funding dynamics in equity crowdfunding. J. Corp. Financ. 2018. [CrossRef]

17. Beier, M.; Wagner, K. User behavior in crowdfunding platforms-Exploratory evidence from Switzerland. In Proceedings of the Annual Hawaii International Conference on System Sciences, Koloa, HI, USA, 5-8 January 2016. [CrossRef]

18. Marom, D.; Robb, A.; Sade, O. Gender Dynamics in Crowdfunding (Kickstarter): Evidence on Entrepreneurs, Investors, Deals and Taste-Based Discrimination. SSRN 2016. [CrossRef]

19. Dheer, R.J.S. Entrepreneurship by immigrants: A review of existing literature and directions for future research. Int. Entrep. Manag. J. 2018. [CrossRef]

20. Ibrahim, G.; Galt, V. Ethnic Business Development: Toward a Theoretical Synthesis and Policy Framework. J. Econ. Issues 2003. [CrossRef]

21. Moon, Z.K.; Farmer, F.L.; Miller, W.P.; Abreo, C. Identification and Attenuation of Barriers to Entrepreneurship: Targeting New Destination Latino Migrants. Econ. Dev. Q. 2014. [CrossRef]

22. Ram, M.; Theodorakopoulos, N.; Jones, T. Forms of capital, mixed embeddedness and Somali enterprise. Work. Employ. Soc. 2008. [CrossRef]

23. Bengtsson, O.; Hsu, D.H. Ethnic matching in the U.S. venture capital market. J. Bus. Ventur. 2015, 30, 338-354. [CrossRef]

24. Hegde, D.; Tumlinson, J. Does Social Proximity Enhance Business Partnerships? Theory and Evidence from Ethnicity's Role in U.S. Venture Capital. Manag. Sci. 2014, 60, 2355-2380. [CrossRef] 
25. Gompers, P.A.; Mukharlyamov, V.; Xuan, Y. The cost of friendship. J. Financ. Econ. 2016, 119, 626-644. [CrossRef]

26. Rhue, L.; Clark, J. Who Gets Started on Kickstarter? Racial Disparities in Crowdfunding Success. SSRN Electron. J. 2016. [CrossRef]

27. Buttice, V.; Useche, D. Crowdfunding to Overcome Liability of Outsidership: Drivers of Immigrants' Fundraising Performance. Acad. Manag. Proc. 2019. [CrossRef]

28. Greenberg, J. Inequality and crowdfunding. In Handbook of Research on Crowdfunding; Edward Elgar Publishing: Cheltenham, UK; Northampton, MA, USA, 2019.

29. Greenberg, J.; Mollick, E. Activist Choice Homophily and the Crowdfunding of Female Founders*. Adm. Sci. Q. 2017. [CrossRef]

30. Shapley, L.S. A Value for n-person Games. Contrib. Theory Games 1953. [CrossRef]

31. Feola, R.; Vesci, M.; Marinato, E.; Parente, R. Segmenting "digital investors": Evidence from the Italian equity crowdfunding market. Small Bus. Econ. 2019. [CrossRef]

32. Hervé, F.; Manthé, E.; Sannajust, A.; Schwienbacher, A. Determinants of individual investment decisions in investment-based crowdfunding. J. Bus. Financ. Account. 2019. [CrossRef]

33. Vismara, S.; Benaroio, D.; Carne, F. Gender in entrepreneurial finance: Matching investors and entrepreneurs in equity crowdfunding. In Gender and Entrepreneurial Activity; Edward Elgar Publishing: Cheltenham, UK; Northampton, MA, USA, 2017. [CrossRef]

34. Blau, Z.S. Structural Constraints on Friendships in Old Age. Am. Sociol. Rev. 1961. [CrossRef]

35. Lazarsfeld, P.F.; Merton, R.K. Friendship as a Social Process: A Substantive and Methodological analysis. Free. Control Mod. Soc. 1954, 18, 18-66. [CrossRef]

36. McPherson, M.; Smith-Lovin, L.; Cook, J.M. Birds of a Feather: Homophily in Social Networks. Annu. Rev. Sociol. 2001, 27, 415-444. [CrossRef]

37. Graham, S.; Taylor, A.Z.; Ho, A.Y. Race and ethnicity in peer relations research. In Handbook of Peer Interactions, Relationships, and Groups; The Guilford Press: New York, NY, USA, 2009.

38. Yinger, J.M. Ethnicity. Annu. Rev. Sociol. 1985, 11, 151-180. [CrossRef]

39. Aldrich, H.E.; Waldinger, R. Ethnicity and Entrepreneurship. Annu. Rev. Sociol. 1990, 16, 111-135. [CrossRef]

40. Horvat, E.-A.; Papamarkou, T. Gender Differences in Equity Crowdfunding. In Proceedings of the Fifth AAAI Conference on Human Computation and Crowdsourcing, Québec City, QC, Canada, 23-26 October 2017.

41. Tajfel, H. Social identity and intergroup behaviour. Soc. Sci. Inf. 1974. [CrossRef]

42. Granovetter, M. The Strength of Weak Ties: A Network Theory Revisited. Sociol. Theory 1983. [CrossRef]

43. Granovetter, M.S. The Strength of Weak Ties The Strength of Weak Ties1. Am. J. Sociol. 1973. [CrossRef]

44. Putnam, R.D. E pluribus unum: Diversity and community in the twenty-first century the 2006 johan skytte prize lecture. Scan. Polit. Stud. 2007. [CrossRef]

45. Beauhurst. Crowdfunding Index, Crowdfunding in the UK. 2017. Available online: https://about.beauhurst. com/blog/equity-investment-update-q3-2018/ (accessed on 18 October 2018).

46. Hart, D.M.; Acs, Z.J. High-tech immigrant entrepreneurship in the united states. Econ. Dev. Q. 2011, 25, 116-129. [CrossRef]

47. Ruef, M.; Aldrich, H.E.; Carter, N.M. The Structure of Founding Teams: Homophily, Strong Ties, and Isolation among U.S. Entrepreneurs. Am. Sociol. Rev. 2003, 68, 195. [CrossRef]

48. Kenney, M.; Patton, D. Gender, ethnicity and entrepreneurship in initial public offerings: Illustrations from an open database*. Res. Policy 2015. [CrossRef]

49. Bhagwat, V.; Liu, X. The Role of Trust in Information Processing: Evidence from Security Analysts. Account. Rev. 2019. [CrossRef]

50. Kerr, W. The Ethnic Composition of U.S. Inventors; Working Paper no. 08-006; Harvard Business School: Boston, MA, USA, 2008.

51. Kerr, W.R.; Lincoln, W.F. The supply side of innovation: H-1B visa reforms and U.S. ethnic invention. J. Labor Econ. 2010. [CrossRef]

52. Kerr, W.R. Ethnic scientific communities and international technology diffusion. Rev. Econ. Stat. 2008. [CrossRef]

53. Mateos, P. A review of name-based ethnicity classification methods and their potential in population studies. Popul. Space Place 2007. [CrossRef] 
54. Clark, K.; Drinkwater, S. Recent trends in minority ethnic entrepreneurship in Britain. Int. Small Bus. J. 2010. [CrossRef]

55. Ram, M.; Smallbone, D.; Deakins, D. The Finance and Business Support Needs of Ethnic Minority Firms in Britain; British Bankers Association: London, UK, 2002.

56. Smallbone, D.; Ram, M.; Deakins, D.; Baldock, R. Access to Finance by Ethnic Minority Businesses in the UK. Int. Small Bus. J. 2003. [CrossRef]

57. Mohammadi, A.; Shafi, K. Gender differences in the contribution patterns of equity-crowdfunding investors. Small Bus. Econ. 2018, 50, 275-287. [CrossRef]

58. Brush, C.G.; Carter, N.M.; Gatewood, E.J.; Greene, P.G.; Hart, M. Gatekeepers of Venture Growth: A Diana Project Report on the Role and Participation of Women in the Venture Capital Industry. SSRN Electron. J. 2004. [CrossRef]

59. Harrison, R.T.; Mason, C.M. Does gender matter? Women business angels and the supply of entrepreneurial finance. Entrep. Theory Pract. 2007, 31, 445-472. [CrossRef]

60. Jianakoplos, N.A.; Bernasek, A. Are women more risk averse? Econ. Inq. 1998. [CrossRef]

61. Carter, S.; Mwaura, S.; Ram, M.; Trehan, K.; Jones, T. Barriers to ethnic minority and women's enterprise: Existing evidence, policy tensions and unsettled questions. Int. Small Bus. J. Res. Entrep. 2015. [CrossRef]

62. Bates, T.; Jackson, W.E.; Johnson, J.H. Advancing research on minority entrepreneurship. Ann. Am. Acad. Pol. Soc. Sci. 2007. [CrossRef]

63. Roper, S.; Hales, C.; Bryson, J.R.; Love, J. Measuring Sectoral Innovation Capability in Nine Areas of the UK Economy; NESTA: London, UK, 2009. [CrossRef]

64. Cumming, D.; Meoli, M.; Vismara, S. Investors' choices between cash and voting rights: Evidence from dual-class equity crowdfunding. Res. Policy 2019. [CrossRef]

65. Cumming, D.J.; Leboeuf, G.; Schwienbacher, A. Crowdfunding models: Keep-It-All vs. All-Or-Nothing. Financ. Manag. 2019. [CrossRef]

66. Leland, H.E.; Pyle, D.H. Informational asymmetries, financial structure, and financial intermediation. $J$. Financ. 1977. [CrossRef]

67. Croson, R.; Gneezy, U. Gender differences in preferences. J. Econ. Lit. 2009. [CrossRef]

68. Owen, G. Values of Games with a Priori Unions. Math. Econ. Game Theory 1977. [CrossRef]

69. Shorrocks, A.F. Decomposition procedures for distributional analysis: A unified framework based on the Shapley value. J. Econ. Inequal. 2013. [CrossRef]

70. Barber, B.M.; Odean, T. Boys will be boys: Gender, overconfidence, and common stock investment. $Q$. J. Econ. 2001. [CrossRef]

71. Portes, A.; Jensen, L. The Enclave and the Entrants: Patterns of Ethnic Enterprise in Miami before and after Mariel. Am. Sociol. Rev. 1989. [CrossRef]

72. Portes, A.; Manning, R. The Immigrant Enclave: Theory and Empirical Examples; Relat Academic Press: Orlando, FL, USA, 1986; pp. 47-64.

73. Polzin, F.; Sanders, M.; Stavlöt, U. Do investors and entrepreneurs match?-Evidence from The Netherlands and Sweden. Technol. Forecast. Soc. Chang. 2018, 127, 112-126. [CrossRef]

74. Allen, F.; Demirguc-Kunt, A.; Klapper, L.; Martinez Peria, M.S. The foundations of financial inclusion: Understanding ownership and use of formal accounts. J. Financ. Intermediation 2016. [CrossRef]

75. Demirgüç-Kunt, A.; Klapper, L. Measuring Financial Inclusion: The Global Findex Database. World Bank Policy Res. Work. Pap. 2012, 6025, 1-61. [CrossRef]

76. Demirguc-Kunt, A.; Klapper, L.; Singer, D.; Ansar, S.; Hess, J. The Global Findex Database 2017: Measuring Financial Inclusion and the Fintech Revolution; World Bank Group: Washington, DC, USA, 2018. [CrossRef]

77. Sarma, M. Index of Financial Inclusion; Working Paper No 215; Indian Council for Research on International Economic Relations: New Delhi, India, 2008.

78. Smith-Hunter, A.E.; Boyd, R.L. Applying theories of entrepreneurship to a comparative analysis of white and minority women business owners. Women Manag. Rev. 2004. [CrossRef]

79. World Bank 2018. From Spreadsheets to Suptech: Technology Solutions for Market Conduct Supervision. Available online: http://documents.worldbank.org/curated/en/612021529953613035/pdf/127577-REVISEDSuptech-Technology-Solutions-for-Market-Conduct-Supervision.pdf (accessed on 15 June 2019).

80. World Bank Fintech: The Experience So Far. 2019. Available online: http://pubdocs.worldbank.org/en/ 361051561641115477/pdf/Fintech-executive-summary.pdf (accessed on 24 June 2019). 
81. Calic, G.; Mosakowski, E. Kicking Off Social Entrepreneurship: How A Sustainability Orientation Influences Crowdfunding Success. J. Manag. Stud. 2016. [CrossRef]

82. Chan, H.F.; Moy, N.; Schaffner, M.; Torgler, B. The effects of money saliency and sustainability orientation on reward based crowdfunding success. J. Bus. Res. 2019. [CrossRef]

83. Bento, N.; Gianfrate, G.; Thoni, M.H. Crowdfunding for sustainability ventures. J. Clean. Prod. 2019. [CrossRef]

84. Rey-Martí, A.; Mohedano-Suanes, A.; Simón-Moya, V. Crowdfunding and social entrepreneurship: Spotlight on intermediaries. Sustainability 2019, 11, 1175. [CrossRef]

85. Cumming, D.J.; Leboeuf, G.; Schwienbacher, A. Crowdfunding cleantech. Energy Econ. 2017. [CrossRef]

(C) 2020 by the authors. Licensee MDPI, Basel, Switzerland. This article is an open access article distributed under the terms and conditions of the Creative Commons Attribution (CC BY) license (http://creativecommons.org/licenses/by/4.0/). 